\title{
Thermal Treatment of Syrian Shot Coke
}

\author{
Hassasn Al-Haj Ibrahim* \\ Department of Chemical Engineering, Al-Baath University, Syria
}

Submission: April 25, 2017; Published: July 17, 2017

*Corresponding author: Hassasn Al-Haj Ibrahim, Department of Chemical Engineering, Al-Baath University, Homs, Syria

Email: Sanjim84@yahoo.com

\begin{abstract}
Shot coke is a by-product of the delayed coking process, and can represent a significant part of the petroleum coke produced. It is comprised in general of two basic types, namely regular shot coke and clustered or agglomerated coke. Shot coke is, however, of little or no commercial value, particularly if it has a high sulphur content, as is becoming increasingly the case in most oil refineries. Upgrading the coke and reducing its sulphur content would add considerably to its economic value both as a fuel and/or for making aluminium anodes. Towards this end, samples of Syrian shot coke, produced by the delayed coking unit at the Homs Oil Refinery, were thermally treated at high temperatures and increased residence time. A coke of higher quality was thereby obtained, with reduced sulphur content (1\%) and higher real density $(1.9 \mathrm{~g} /$ $\mathrm{cm}^{3}$ ). The observed weight loss was minimal, and the decrease in the calorific value was less than the average expected for other types of petroleum coke.
\end{abstract}

Keywords: Petroleum coke; Shot coke; Thermal treatment

\section{Shot Coke}

Shot coke is an abnormal form of delayed petroleum coke. Physically it can be comprised of:

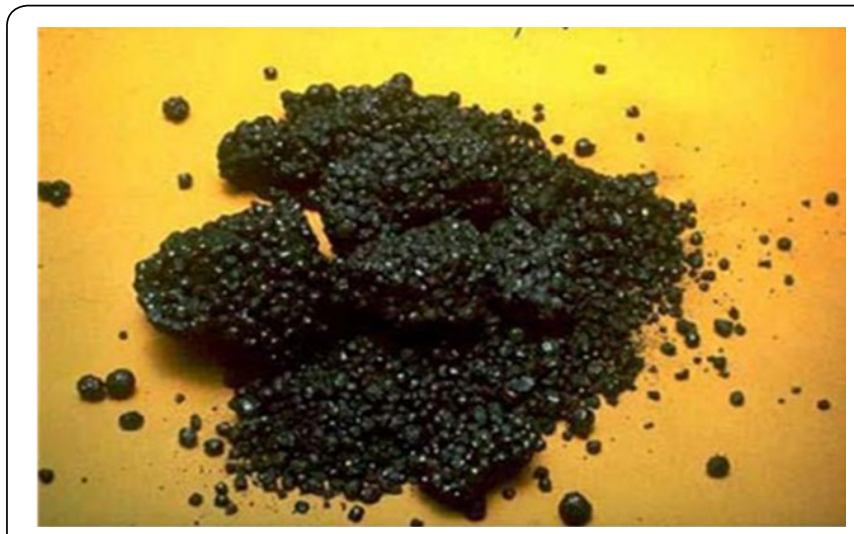

Figure 1: Shot coke.

a) Individual spheres, which are hard, dense, vitreous, nonporous spheres that may or may not be fractured (Figure 1). Normally, most shot coke spheres are uniformly sized (1-2mm dia or 2-6 $\mathrm{mm}$ ), but they can range from as small as buckshot to as large as basket balls. It is thought that smaller spheres are made when very high feed rates are used in the coker. Larger spheres (up to $20 \mathrm{~mm}$ ) and more mixed sizing tend to occur when a coker just begins to produce shot coke. Very large spheres (up to the size of basketballs) are usually made up of a fused aggregation of uniformly-sized smaller spheres [1].

b) Agglomerated or clustered spheres, where individual spheres may form an aggregate consisting of smaller individual spheres of $1 \mathrm{~mm}$ to $10 \mathrm{~mm}$ in size, bonded together somewhat loosely. An aggregate may range in size from a few millimeters to as much as 30 or more centimeters.

c) Bonded spheres or matrix shot. This appears as spheres of coke that melted together on formation. When it fractures, it will fracture across the spheres, rather than at the boundaries of the spheres as in agglomerated shot.

The structure of shot coke is described by the use of Montage microphotographs, comparing the structure to that of sponge coke. The photographs reveal the fine-mosaic, high-density structure of shot coke [2].

Shot coke, while it may look like it is entirely made up of shot, is not necessarily so. Shot coke is unique in that the small spheres have a slick shiny exterior coating of needle or acicular type carbon, but the inside of each sphere contains isotropic or amorphous type coke. A microscopic study by Marsh, Calvert and Bacha showed that the shot coke spheres consist of a finegrained mosaic core (0.5-1.5 $\mu \mathrm{m} \mathrm{dia.)} \mathrm{surrounded} \mathrm{by} \mathrm{a} \mathrm{thin,} \mathrm{slick}$ outer skin, $50 \mu \mathrm{m}$ thick, of more well-developed mesosphere 


\section{Recent Advances in Petrochemical Science}

coke and of coarse-grained mosaic (5.0-10.0 $\mu \mathrm{m}$ dia.) and small domains (10-60 $\mu \mathrm{m}$ dia.). Centrally located stress cracks are thought to be due to shrinkage of the core structure. Scanning electron microscopy photos of shot coke spheres which had been partially fractured show that the outer skin must be a discrete layer since it is fractured in a different pattern than the core [1-3].

Other types of coke, notably sponge coke, may also have some embedded shot coke in the coke structure.

Shot coke is usually produced from very heavy, low API, feedstocks that have lower levels of aromaticity and higher levels of asphaltenes and heteroatoms, i.e. nitrogen, sulphur and oxygen and other associated metals. Presumably there exists a sufficiently high content of aliphatic carbon and hydrogen and this could lead to significant volatile evolution within the coking drum [4].

Shot coke is produced as the oil flows into the coke drum. With the light ends flashing off, small spherical droplets of heavy tar are suspended in the flow. These tar droplets rapidly form coke due to the exothermic heat produced by asphaltene polymerization. Their formation is caused by the shearing action of a highly turbulent dynamic environment which results from high fluid velocities and vaporisation of existent and/or cracked products. Rapid chemical reactions which occur within the droplets while they are suspended in the vapour phase increase the viscosity of the developing ball of immature coke. Before the droplets can return back to and become an integral part of the bulk liquid phase the viscosity has increased sufficiently to "fix" the macroscopic form and microstructure of the shot coke. The coke balls formed then fall back into the drum as discrete little spheres. In the main channel up through the drum, some of the spheres will roll around and stick together forming large balls as large as $25 \mathrm{~cm}$. When these large balls are broken, they are found to be composed of many of the smaller balls [1-3].

Shot coke can only be produced in a highly turbulent dynamic environment such as that found in commercial delayed cokers. It is very difficult to produce in conventional pilot plants with low superficial velocity without specially designed modifications. Also, it cannot be produced in a laboratory pot coker; although cokes formed from a shot coke prone feed stock will exhibit the same microstructure and coefficient of thermal expansion regardless of whether they are generated in a commercial-scale delayed or laboratory pot coker. Such cokes produced in a laboratory pot coker will not however have the microscopic form of shot coke [1].

The concentration of shot coke particles can vary from only a small zone in a coke drum to making up the entire coke mass. These particles are generally harder than sponge coke and can be a problem on cutting and grinding; and on opening the delayed coker they can pour uncontrolled from the drum.
Shot coke is normally found at lower levels in a coke drum but may, on occasion, be found in the upper section of the drum. Occasionally it may also appear on top of sponge coke [1].

The formation of shot coke is favored in most instances by a shorter delayed coking cycle, higher superficial velocity, low coke drum pressures, low recycle ratios and high coke drum temperatures. Such conditions lead to the increase of the asphaltene content, relative reactivity of the coker feedstock and immediate coke precursors, as well as the degree of turbulence in the coke drum. Fluidization in the coke drum may also cause shot coke formation, and a coker feedstock high in oxygen content can produce shot coke [3].

Reducing the coke drum temperature can be an effective means of eliminating shot coke formation, but normally increases coke yield. The additional coke is produced from the internal recycle or heavy gas oil constituents which alone would produce a well-ordered coke; in combination they dilute shot coke forming constituents [1].

Shot coke should not be confused with fluid coke which is formed in the fluid coking process. This is a completely different process from delayed coking, in which the coke is produced by spraying the heated residuum into a fluidized bed of hot coke particles which are maintained at 1.4- 2.7 bars and $500^{\circ} \mathrm{C}$. The feed vapours are cracked while forming a liquid film on the coke particles. The residuum is formed immediately into coke with complete disorientation of the crystals in the hot coke particle. The particles grow by layers until they are removed and new seed coke particles are added. Fluid coke has smaller diameter spheres than shot coke.

Shot coke tends to be more isotropic than other types of coke and its optical texture is of fine-grained mosaic $(\sim 1 \mu \mathrm{m}$ dia.) [4]. The carbon in shot coke is in the form of ribbon and lenticular/granular anisotropic domains arranged in concentric patterns. Magnification of the surface fractures show whirled, or nonlinear structure in the isotropic shot coke [1].

Shot coke is unreactive and of relatively low electrical conductivity. It is characterized by its lack of permeability, low porosity, low Hardgrove Grindability Index (which may be as low as 2.7) and high density which makes it difficult to crush. When the Hardgrove Grindability index in a coke drops suddenly, it is an indication of the coke becoming isotropic and of a heightened potential for shot coke formation.

The coefficient of thermal expansion is used sometimes to determine a quantitative value describing coke structure. The coke is calcined, ground to a flour, mixed with coal tar pitch, extruded to orientate particles into.

$\mathrm{mm}$ rods, baked to $850^{\circ} \mathrm{C}$ and graphitized to $2900^{\circ} \mathrm{C}$, and then the difference in expansion at $0^{\circ} \mathrm{C}$ and $50^{\circ} \mathrm{C}$ is measured for coefficient of thermal expansion determination. For shot 
coke, this coefficient of thermal expansion is rather high. It is typically greater than $20\left(\mathrm{~cm} / \mathrm{cm} /{ }^{\circ} \mathrm{C} \times 10^{-7}\right)[3]$

Shot coke can have low mineral impurities (metal and sulphur) but it is usually rich in such impurities because it is produced most often from feedstocks derived from high sulphur, high metals content crude oils [3]. Shot coke is in general of low or no commercial value; and although it may be used as a fuel, it is less desirable in this usage than sponge coke The chief drawback to its use as a fuel is its extreme hardness which increases the cost of grinding [1,5-7].

Shot coke cannot be used in making aluminium anodes. While low grindability cokes are preferred since such cokes yield calcined coke which exhibits a very high vibrated bulk density which is desirable in an aluminium prebaked anode, good bonding with binder coal tar pitch is prevented by the slickness of the outer layer of the shot spheres, their lack of permeability and porosity and dissimilarity of the outer needle coke layer of the shot sphere which has a very low coefficient of thermal expansion and the interior core of the sphere which, being isotropic, has a very high coefficient of thermal expansion. The higher coefficient of thermal expansion of the shot coke is also thought to cause thermal shock cracking of the anode when it is set in a hot cell [1-4].

On the other hand, the special properties of shot coke, including its isotropy, spherical shape, hardness, high coefficient of thermal expansion and high density make it useful for certain specialty applications, e. g, titanium dioxide manufacture, nuclear graphite (if boron content is low), and graphite mould stocks.

For the manufacture of special graphite for nuclear reactors, gilsonite coke, i.e. shot coke produced from Gilsonite ore, may be used. Air blowing of a sponge coke precursor before delayed coking can also be used to generate a shot coke forming feedstock, the ultimate objective being production of an isotropic coke for nuclear graphite manufacture [1].

\section{Syrian Delayed Coke}

Syrian delayed coke is coke produced by the delayed coking unit at the Homs Oil Refinery. This unit was designed and built during the late sixties of last century for the purpose of maximizing gasoline and distillate yields using a feedstock of residue materials. The Petcoke produced is considered merely as a by-product of little commercial value. This is mainly because of its high sulphur content and the high percentage of fines produced.

There are at least four basic types of delayed petcoke with different microstructures due to differences in operating variables and nature of feedstock. The basic coke types are: needle coke, honeycomb coke, sponge coke and shot coke. Of these four types, only the last two types, namely sponge and shot cokes are produced at the Homs Oil Refinery. In order to characterise Syrian green petroleum coke, samples of the coke were classified and divided into five basic types, namely shot coke, clustered shot coke, porous sponge coke, continuous sponge coke and fines. Significant differences were observed in the properties of the five types of the Syrian petroleum coke considered, particularly ash and VM contents [8].

\section{Thermal Treatment}

Thermal treatment of petcoke is the most promising process for the desulphurization of petcoke, and can be the only one possible when other techniques prove to be difficult or inefficient as was found in at least one case with Syrian petcoke $[9,10]$. By thermal treatment is meant the process whereby a fixed static bed of petcoke is heated under atmospheric pressure in an inert atmosphere to a specified temperature and then kept at that temperature for a specified period of time [9]. Thermal treatment of Syrian petcoke in general and sponge coke in particular has already been made [1,11-13] with encouraging results, but in view of the significant differences between the different coke types, separate treatment of shot coke was deemed of benefit as shot coke represents a major part of Syrian coke production.

\section{Experimental Work}

For the present work, samples of Syrian shot coke were taken from the coke heaps stored to the west of the Homs Oil refinery. The coke samples were classified and divided into regular shot coke and clustered or agglomerated shot coke. Matrix shot or bonded spheres of coke that melted together on formation were discarded. (Tables 1 \& 2) give the results of the proximate and ultimate analysis for the coke samples.

Table 1: Proximate Analyses of Syrian shot coke, Air-dried basis.

\begin{tabular}{|c|c|c|}
\hline Property & $\begin{array}{c}\text { Regular shot } \\
\text { coke }\end{array}$ & $\begin{array}{c}\text { Clustered } \\
\text { shot coke }\end{array}$ \\
\hline Ash (wt. \%) & 0.2 & 0.1 \\
\hline Moisture (wt. \%) & 0.2 & 0.4 \\
\hline Fixed carbon (wt. \%) & 89.7 & 89.7 \\
\hline Volatile Matter (wt. \%) & 9.9 & 9.8 \\
\hline Sulphur (wt. \%) & 7.9 & 8 \\
\hline Gross Calorific Value (kJ/kg) & $34.7 \times 103$ & $34.3 \times 103$ \\
\hline Real density (g/cm ${ }^{3}$ ) & 1.4 & 0.21 \\
\hline Surface area (B.E.T.) $\left(\mathrm{m}^{2} / \mathrm{g}\right)$ & 0.23 & 1.37 \\
\hline
\end{tabular}

Table 2: Ultimate Analyses of Syrian shot coke, Dry, ash-fbasis.

\begin{tabular}{|c|c|}
\hline & Regular shot Coke \\
\hline Carbon & 85 \\
\hline Hydrogen & 4.3 \\
\hline Nitrogen & 1.1 \\
\hline Oxygen & 1.7 \\
\hline Sulphur & 7.9 \\
\hline C/H (wt.) & 19.8 \\
\hline
\end{tabular}

The coke samples were thermally treated in an inert atmosphere of nitrogen at atmospheric pressure. The 


\section{Recent Advances in Petrochemical Science}

treatment was carried out in an electrical tube furnace heated by a SiC element fully covering the working tube. The outside diameter of the working tube is $59 \mathrm{~mm}$, and the heated length is $250 \mathrm{~mm}$. A PtRh-Pt thermocouple is placed in the centre of the heating zone and is lead to the temperature control unit. The conditions used in the treatment were such that were expected to lead to a maximum rate of desulphurization at moderately high temperatures [11]. Table 3 is a summary of the treatment conditions used. A summary of the results of the thermal treatment is shown in Table 4.

Table 4: Results of the thermal treatment.

\begin{tabular}{|c|c|c|c|c|c|c|c|}
\hline \multirow{2}{*}{ Temperature $\mathrm{K}$} & \multicolumn{4}{|c|}{ Regular shot coke } & \multicolumn{3}{|c|}{ Clustered shot coke } \\
\hline & Wt loss \% & $\mathrm{CV} \times 103 \mathrm{~kJ} / \mathrm{kg}$ & S wt \% & DR10 - 20 & Wt loss \% & $\mathrm{CV} \times 103 \mathrm{~kJ} / \mathrm{kg}$ & S wt \% \\
\hline 300 & - & 34.7 & 7.9 & 1.4 & - & 34.3 & 8 \\
\hline 500 & 0.6 & 34.7 & 7.9 & 1.4 & 0.6 & 34.2 & 8 \\
\hline 775 & 4.1 & 34.5 & 7.9 & 1.45 & 3.9 & 34.5 & 7.8 \\
\hline 875 & 4.1 & 34.8 & 7.8 & 1.48 & 3.7 & 33.8 & 7.9 \\
\hline 975 & 8.2 & 32.4 & 7.3 & 1.57 & 7.8 & 32.4 & 7.4 \\
\hline 1075 & 8.5 & 32.3 & 7.6 & 1.74 & 8.2 & 32.3 & 7.4 \\
\hline 1175 & 9.1 & 31.9 & 6.1 & 1.82 & 7.3 & 32 & 6.9 \\
\hline 1450 & 12.2 & 31.8 & 3.7 & 1.89 & 12.2 & 31.6 & 3.8 \\
\hline 1550 & 14.1 & 31.8 & 3.6 & 1.75 & 14.2 & 31.9 & 3.4 \\
\hline 1650 & 17.9 & 31.8 & 1.4 & 1.9 & 18.1 & 31.9 & 1.5 \\
\hline 1700 & 18.6 & 32 & 1 & 1.92 & 20.7 & 32.5 & 1 \\
\hline
\end{tabular}

\section{Sulphur Removal}

Table 5: Average degree of desulphurization for shot and other types of Syrian petroleum coke.

\begin{tabular}{|c|c|c|c|}
\hline \multirow{2}{*}{$\begin{array}{c}\text { Temperature } \\
\text { range (K) }\end{array}$} & \multicolumn{3}{|c|}{ Average degree of desulphurization(\%) } \\
\cline { 2 - 4 } & Regular shot & Clustered & Other types \\
\hline $300-1075$ & 4 & 8 & 7 \\
\hline $1075-1175$ & 19 & 6 & 18 \\
\hline $1175-1450$ & 30 & 39 & 23 \\
\hline $1450-1550$ & 1 & 5 & 13 \\
\hline $1550-1650$ & 28 & 24 & 22 \\
\hline $1650-1700$ & 5 & 6 & 7 \\
\hline
\end{tabular}

Table 5 shows the results of sulphur removal for both types of shot coke as compared with other types of Syrian coke in general. Similar trends are observed in both cases, with a notable exception in the temperature range $1450-1550 \mathrm{~K}$ where a marked drop in the degree of desulphurization of shot coke was observed. At temperature $\geq 1500 \mathrm{~K}$ desulphurization is normally inhibited by the formation of thermally-stable metal sulphides [14]. This is mostly the case with shot coke, which is usually rich in metal impurities as was pointed out above. In the temperature range 1075-1175 K, the expected increased degree of desulphurization is not observed in the case of the clustered shot coke, with only $6 \%$ sulphur removal as compared to $19 \%$ for regular shot coke and $18 \%$ for other types of coke. Most of the sulphur removed during this stage
Table 3: Conditions of Thermal Treatment.

\begin{tabular}{|c|c|}
\hline Average weight of treated sample & $10 \mathrm{~g}$ \\
\hline Coke Size range & $0.85-1.60 \mathrm{~mm}$ \\
\hline Rate of heating & $3.5^{\circ} \mathrm{C} / \mathrm{min}$ \\
\hline Gas atmosphere & $\mathrm{N} 2$ \\
\hline Pressure & Atmospheric \\
\hline Rate of nitrogen flow & $0.5 \mathrm{l} / \mathrm{min} / \mathrm{g}$ \\
\hline Residence time at the maximum temperature & $180 \mathrm{~min}$ \\
\hline
\end{tabular}

is derived from the decomposition of the thermally-stable sulphur compounds bound in side chains [11]. These results may indicate a significant difference between clustered coke and other types of coke in the amount and/or the nature of sulphur compounds bound in side chains, but further work is necessary before a definite conclusion is reached (Table $3 \& 4$ ).

\section{Density Increase}

The true density of petcoke is expected to increase continuously with increasing treatment temperature. The rate of this increase is different, however, at different temperature ranges. Three stages of density change were recognized [12]

a) An initial stage $(300-800 \mathrm{~K})$, with minimal density increase due probably to the removal of moisture and some volatile matter in the coke. The density increase observed was $0.05 \mathrm{~g} / \mathrm{cm}^{3}$ in the case of regular shot coke.

b) A second stage (800-1200) characterized by rapid increase in density related to the evaporation of the volatile matter adsorbed on the coke surface or in the pores. For regular shot coke, with $9.9 \mathrm{VM}$ (wt.\%), the density increased during this stage by $0.47 \mathrm{~g} / \mathrm{cm}^{3}$.

c) A final stage (1200-1700), where the density increase may be related to the rate of sulphur removal. The density increased by $0.10 \mathrm{~g} / \mathrm{cm}^{3}$ for regular shot coke. 


\section{Recent Advances in Petrochemical Science}

\section{Calorific Value}

The calorific value decreases, in general, with increasing temperature of the thermal treatment. However, there were observed two exceptions to this rule, where the calorific value increased rather than decreased. A slight increase in the calorific value was observed towards the end of the first initial stage of thermal treatment $(300-1200 \mathrm{~K})$. This is the overall effect of the evaporation and removal of moisture and volatile matter which take place during this stage, where the removal of moisture, as an inert material, has an opposite effect on the calorific value to that of removing the volatile matter. Whereas the removal of moisture is accompanied by an increase of the calorific value, the removal of the volatile matter tends to lower this value. The overall effect of the thermal treatment is therefore a factor of both volatile matter and moisture content. Since the volatile matter content of shot coke is lower, in general, than for other types of coke, the effect of the removal of VM on the calorific value is expected to be less also, with the result that the increase in the calorific value is more pronounced for shot coke.

The calorific value was also observed to increase slightly in the temperature range $1650-1700 \mathrm{~K}$. This must be related no doubt to the decreased sulphur content, as the heat of combustion of sulphur $(9420 \mathrm{~kJ} / \mathrm{kg})$ is considerably less than that of carbon $(33820 \mathrm{~kJ} / \mathrm{kg})$. A similar result was also obtained with other types of coke [11].

\section{Weight Loss}

The observed weight loss at the conclusion of the thermal treatment varied between 19 and 21\%. This is in agreement with the generally observed weight loss for other types of coke which is normally of the order of $20 \%$ or so. This amount corresponds to the moisture and volatile matter content of the coke as well as to the amount of sulphur removed.

\section{Conclusion}

Effective desulphurization of shot coke was achieved by means of thermal treatment to a temperature of $1700 \mathrm{~K}$ and increased residence time (180 minutes). The treated coke has a low sulphur content (1\%) and a high real density $(1.9 \mathrm{~g} /$ $\mathrm{cm}^{3}$ ). The adverse effects normally associated with thermal Treatments at high temperatures were minimal.

\section{References}

1. Ellis PJ (1996) Shot coke, Light Metals, pp. 477-484.

2. Mochida I, Furuno T, Korai Y, Fujitsu H (1986) Studies reveal shot-coke microstructure, suggest ways to minimize its formation. Oil \& Gas J 84(5).

3. Ellis S, Paul CA (1998) Tutorial: Delayed coking fundamentals, AIChE Spring National Meeting's International Conference on Refinery Processes Topical Conference Reprints, LA, pp. 29.

4. March H, Calvert C, Bacha J (1985) Structure and formation of shot coke- A microscopic study. Journal of Materials Science 20(1): 289-302.

5. Figueiredo JL, Mouljin JA (1986) Carbon and coal gasification. In: (Eds.) Figueiredo JL, Mouljin JA, Martinues Nijhoff Publishers, Dordrecht, Netherlands.

6. Meyers, Robert A (1986) Handbook of petroleum refinery processes. ( $3^{\text {rd }}$ Edn), McGraw-Hill Companies, New York, USA.

7. Tulsa, Okla, GL Farrar (1976) NPRA Q \& A Session on refining and petrochemical technology. The Petroleum Publishing Company, USA.

8. Ibrahim HA (2005) Analysis of Syrian green delayed coke, Proceedings of the sixth Egyptian Syrian conference on chemical and petroleum engineering, Syria, p. 22-33.

9. Ibrahim H, Morsi BI (1992) Desulfurization of petroleum coke. Industrial and Engineering Chemistry Research volume 31(8): 18351840 .

10. El-kaddah N, Ezz SY (1973) Thermal desulphurization of ultra high sulphur petroleum coke. Fuel 52:128-129.

11. Ibrahim H, Ali M (2004) The effect of increased residence time on the thermal desulphurization of Syrian petroleum coke. Periodica Polytechnica Ser Chem Eng 48: 53-62.

12. Ibrahim H, Ali MM (2005) Effect of the removal of sulphur and volatile matter on the true density of petroleum coke. Periodica Polytechnica Ser Chem Eng 49: 19-24.

13. Ibrahim $H$ (2006) Thermal treatment of Syrian sponge coke. Journal of King Saud University. Engineering Sciences 8(2): 261-270.

14. Vrbanovic Z (1978) Possibility of using high temperature treatment of petroleum coke to desulphurize it. Nafta (Zagreb) 2: 80-93.

\section{Your next submission with Juniper Publishers} will reach you the below assets

- Quality Editorial service

- Swift Peer Review

- Reprints availability

- E-prints Service

- Manuscript Podcast for convenient understanding

- Global attainment for your research

- Manuscript accessibility in different formats

( Pdf, E-pub, Full Text, Audio)

- Unceasing customer service

Track the below URL for one-step submission https://juniperpublishers.com/online-submission.php 